\title{
Dosage schedule of gentamicin for chronic renal insufficiency in children
}

\author{
HAJIME YOSHIOKA, MASATOSHI TAKIMOTO, ICHIRO MATSUDA, \\ AND SHINZABURO HATTORI \\ From the Departments of Paediatrics, Asahikawa Medical College, and Kumamoto University School of Medicine
}

SUMMARY Gentamicin was given to paediatric patients with chronic renal disease complicated by infections by Gram-negative organisms, in which renal function varied from normal to severely insufficient. Peak serum levels after an intramuscular dose of $1 \mathrm{mg} / \mathrm{kg}$ body weight ranged from $3 \cdot 1$ to $9.4 \mu \mathrm{g} / \mathrm{ml}$, which appeared adequate for therapy. The peak value was not related to the renal function of the individual patients.

The serum half-life of gentamicin correlated inversely with the value for endogenous creatinine clearance. A diagram for the estimation of the serum half-life of gentamicin using the creatinine clearance value is presented. As a practical guide, it is recommended that the dose of gentamicin in children with renal function impairment be $1 \mathrm{mg} / \mathrm{kg}$ given intramuscularly and that the interval between doses be almost three times as long as the serum half-life, which can be estimated by means of the diagram for individual patients. The accuracy and safety of this method were confirmed by treating children with this adjusted dosage schedule.

Because gentamicin is eliminated largely by renal function, toxic effects occur more easily in renal insufficiency than under conditions of normal renal function. On the other hand, gentamicin is frequently indicated in patients with renal impairment to combat infections due to Gram-negative organisms, which are apt to complicate haemodialysis and associated minor surgical procedures. In order to avoid toxicity, several approaches to adjusting dosages in patients with renal disease have been devised (Gingell and Waterworth, 1968; Gyselynck et al., 1971; McHenry et al., 1971; Chan et al., 1972; Cutler et al., 1972).

Since these studies were done almost exclusively on adult patients, a study was needed in paediatric patients. In this report we show firstly, the relationship of the rate of elimination of gentamicin from plasma to renal function in children, and secondly, we propose a schedule for modifying gentamicin dosage using a diagram. Gentamicin was administered to patients with renal insufficiency complicated by infection according to the adjusted dosage, and the accuracy and safety of the method were clinically confirmed.

\section{Patients and methods}

Fifteen patients with various renal diseases were Received 30 June 1977 studied. They ranged in age from 8 to 17 years and in weight from 23 to $60 \mathrm{~kg}$. The renal functions of the patients were diverse, ranging from 5 to $148 \mathrm{ml} / \mathrm{min}$ per $1.73 \mathrm{~m}^{2}$ of the body surface area in endogenous creatinine clearance (Ccr), and from 8.5 to $95.5 \mathrm{mg} /$ $100 \mathrm{ml}(3-34 \mathrm{mmol} / \mathrm{l})$ in blood urea nitrogen. Gentamicin was prescribed on clinical and bacteriological grounds and given intramuscularly in a dose of $1 \mathrm{mg} / \mathrm{kg}$ body weight.

Samples of peripheral blood were collected with appropriate time intervals before and after gentamicin injection. The serum was immediately separated by centrifugation and kept frozen until tested. Concentration of gentamicin in serum samples was determined by the well-plate agar method (Garrod et al., 1973) using Bacillus subtilis PCI 219 as the indicator strain. The half-life of gentamicin in the serum $\left(T \frac{1}{2}\right)$ was estimated by means of the method of least squares. Data were plotted on $\log / \log$ paper, and a diagram indicating the relation of $\mathrm{T}_{2}^{\frac{1}{2}}$ of gentamicin to Ccr was drawn.

Three patients were treated for infections due to Gram-negative organisms by an adjusted dose of gentamicin, using this diagram. Gentamicin was given to these patients in a dosage of $1 \mathrm{mg} / \mathrm{kg}$, at intervals almost 3 times as long as the estimated $\mathrm{T} \frac{1}{2}$. We measured peak levels, and the changes in blood level up to the fourth dose. 


\section{Results}

Correlation between renal function and serum halflife of gentamicin. The age, weight, clinical diagnosis, Ccr, peak serum levels, and estimated half-life of gentamicin in the serum of the 15 patients are listed in Table 1. Peak serum levels were attained 30 to 60 minutes after injection and ranged from $3 \cdot 1$ to 9.4 $\mu \mathrm{g} / \mathrm{ml}$. No appreciable differences were observed in peak serum levels among patients with normal and impaired renal function. A decline of serum concentration was thereafter delayed in patients with decreased renal function. The delay was likely to be proportional to the extent of renal damage. The $T \frac{1}{2}$ value increased sharply when Ccr values went below a level of $20 \mathrm{ml} / \mathrm{min}$ per $1.73 \mathrm{~m}^{2}$ of the body surface area. In a patient who was nephrectomised, the peak level after intramuscular injection of $1 \mathrm{mg} / \mathrm{kg}$ gentamicin was $3.2 \mu \mathrm{g} / \mathrm{ml}$, and $\mathrm{T} \frac{1}{2}$ was 42 hours.

Developing a diagram. The values for $T_{2} \frac{1}{2}$ in Table 1 were plotted against the values for $\mathrm{Ccr}$ on $\log / \log$ paper. They produced a straight line, and the regression equation was calculated to be $\mathrm{y}=2 \cdot 121-0.934 \mathrm{x}$, where $x$ equals $\log (\mathrm{Ccr})$, and $y$ equals $\log \left(T^{\frac{1}{2}}\right)$. Fig. 1 shows the regression line
Table 1 Pharmacokinetics of gentamicin in patients with renal insufficiency

\begin{tabular}{|c|c|c|c|c|c|c|}
\hline $\begin{array}{l}\text { Case } \\
\text { no. }\end{array}$ & $\begin{array}{l}\text { Age } \\
\text { (years) }\end{array}$ & $\begin{array}{l}\text { Weight } \\
(k g)\end{array}$ & $\begin{array}{l}\text { Clinical } \\
\text { diagnosis }\end{array}$ & $\begin{array}{l}\text { Ccr } \\
(\mathrm{ml} / \mathrm{min} \\
\mathrm{per} \\
\left.\mathrm{l} \cdot 73 \mathrm{~m}^{2}\right)\end{array}$ & $\begin{array}{l}\text { Peak } \\
\text { level } \\
(\mu g / m l)\end{array}$ & $\begin{array}{l}\text { Half- } \\
\text { life } \\
(h)\end{array}$ \\
\hline 1 & 12 & 44 & SLE-nephritis & $148 \cdot 0$ & 9.4 & $1 \cdot 2$ \\
\hline 2 & 14 & 50 & Cystitis & $123 \cdot 0$ & 6.0 & $1 \cdot 3$ \\
\hline 3 & 10 & 35 & Healthy & $120 \cdot 0$ & $9 \cdot 0$ & $1 \cdot 5$ \\
\hline 4 & 13 & 35 & $\begin{array}{l}\text { Purpuric } \\
\text { nephritis }\end{array}$ & 117.0 & $4 \cdot 2$ & $1 \cdot 5$ \\
\hline 5 & 8 & 24 & Nephrosis & $115 \cdot 0$ & $3 \cdot 8$ & $1 \cdot 4$ \\
\hline 6 & 12 & 27 & SLE-nephritis & $107 \cdot 5$ & $4 \cdot 2$ & $2 \cdot 0$ \\
\hline 7 & 17 & 30 & $\begin{array}{c}\text { Chronic pye- } \\
\text { lonephritis }\end{array}$ & $70 \cdot 0$ & $4 \cdot 4$ & $2 \cdot 0$ \\
\hline 8 & 15 & 40 & $\begin{array}{l}\text { Chronic } \\
\text { nephritis }\end{array}$ & $64 \cdot 0$ & $6 \cdot 3$ & $3 \cdot 1$ \\
\hline 9 & 13 & 38 & SLE-nephritis & $23 \cdot 5$ & $6 \cdot 3$ & $10 \cdot 5$ \\
\hline 10 & 18 & 60 & $\begin{array}{l}\text { Chronic } \\
\text { nephritis }\end{array}$ & $18 \cdot 1$ & $3 \cdot 9$ & $11 \cdot 7$ \\
\hline 11 & 16 & 50 & SLE-nephritis & $15 \cdot 5$ & $5 \cdot 3$ & $12 \cdot 0$ \\
\hline 12 & 10 & $26 \cdot 5$ & $\begin{array}{l}\text { Chronic } \\
\text { nephritis }\end{array}$ & $14 \cdot 4$ & $6 \cdot 3$ & $6 \cdot 4$ \\
\hline 13 & 10 & 23 & $\begin{array}{l}\text { Purpuric } \\
\text { nephritis }\end{array}$ & $9 \cdot 5$ & $3 \cdot 1$ & $16 \cdot 1$ \\
\hline 14 & 13 & 30 & $\begin{array}{l}\text { Chronic } \\
\text { nephritis }\end{array}$ & $8 \cdot 1$ & $6 \cdot 4$ & $17 \cdot 2$ \\
\hline 15 & 15 & 46 & $\begin{array}{l}\text { Chronic } \\
\text { nephritis }\end{array}$ & $5 \cdot 0$ & $4 \cdot 2$ & $27 \cdot 0$ \\
\hline
\end{tabular}

SLE = systematic lupus erythematosus; $\mathbf{C c r}=$ endogenous creatinine clearance.

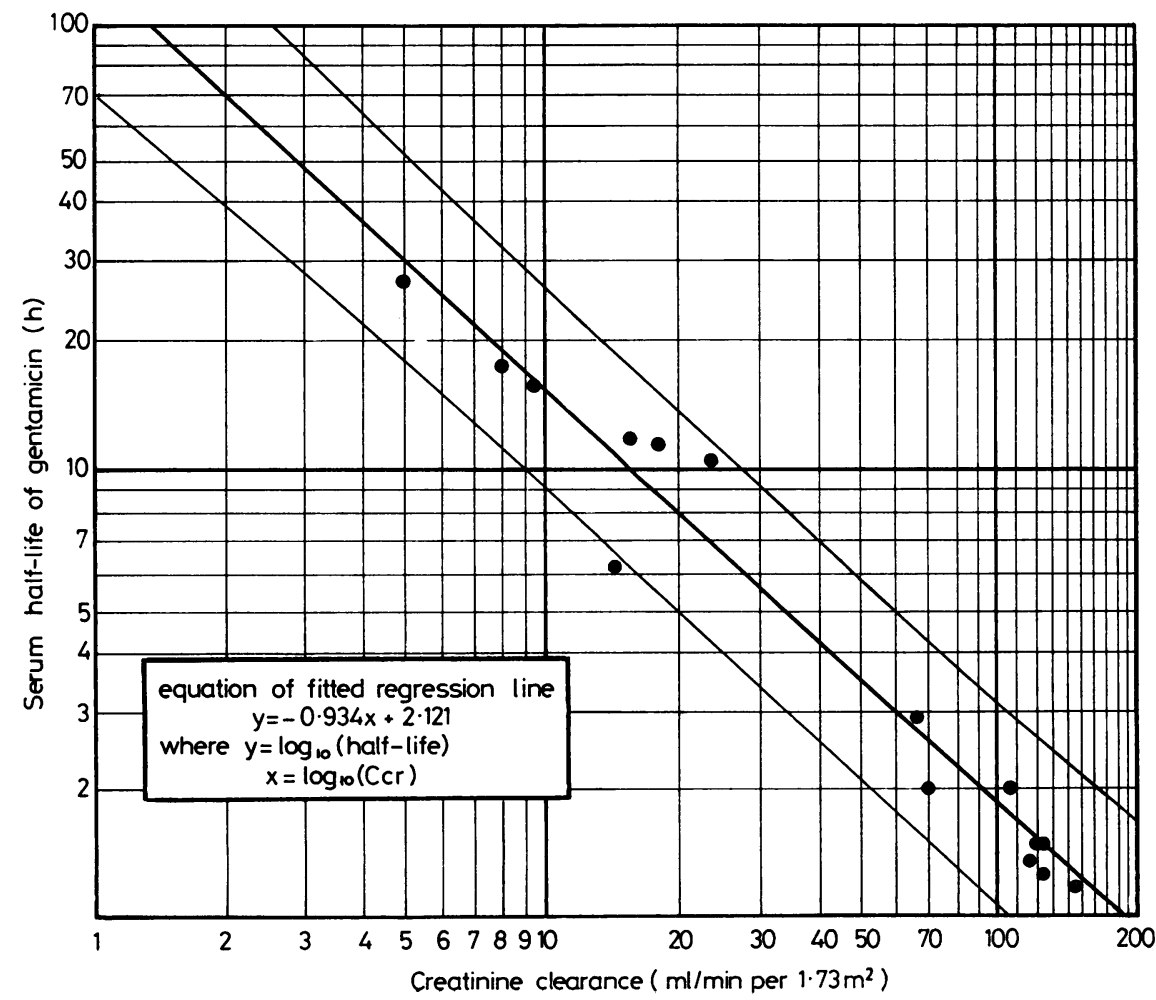

Fig. 1 Correlation between creatinine clearance and serum half-life of gentamicin in 15 subjects. Upper and lower $95 \%$ confidence limits are shown. 
relating $\mathrm{T} \frac{1}{2}$ to $\mathrm{Ccr}$, with the calculated $95 \%$ confidence limits for individual patients. From this it is possible to predict the $T \frac{1}{2}$ when the $\mathrm{Ccr}$ of the patient is known. Thus, the diagram is of clinical importance, since it allows adjustment of the dosage interval of gentamicin in children with varying renal function.

Testing the adjusted dosage schedule in clinical practice. Infections due to Gram-negative bacteraemia in 3 children with renal disease were treated with the adjusted dosage schedule of gentamicin. Gentamicin was given to the patients in an intramuscular dosage of $1 \mathrm{mg} / \mathrm{kg}$ body weight and with the intervals estimated by Fig. 1. The data on these patients are given in Table 2 . In Case $\mathbf{A}$ the dosage

Table 2 Patients treated by adjusted gentamicin dosage schedule

\begin{tabular}{|c|c|c|c|c|c|c|}
\hline \multirow[b]{2}{*}{$\begin{array}{l}\text { Case } \\
\text { no. }\end{array}$} & \multirow[b]{2}{*}{$\begin{array}{l}\text { Age } \\
\text { (years) }\end{array}$} & \multirow[b]{2}{*}{$\begin{array}{l}\text { Weight } \\
(\boldsymbol{k g})\end{array}$} & \multirow{2}{*}{$\begin{array}{l}\text { Ccr } \\
(\mathrm{ml} / \mathrm{min} \\
\left.\operatorname{per} 1.73 \mathrm{~m}^{2}\right)\end{array}$} & \multirow{2}{*}{$\begin{array}{l}\text { Calculated } \\
T_{\frac{1}{2}} \\
\text { (hours) }\end{array}$} & \multicolumn{2}{|c|}{$\begin{array}{l}\text { Intramuscular } \\
\text { gentamicin }\end{array}$} \\
\hline & & & & & $\begin{array}{l}\text { Dose } \\
(m g)\end{array}$ & $\begin{array}{l}\text { Interval } \\
\text { (h) }\end{array}$ \\
\hline $\mathbf{A}$ & 13 & 44 & 13.9 & $11 \cdot 3$ & 44 & 25 \\
\hline B & 10 & 31 & $46 \cdot 2$ & $3 \cdot 7$ & 30 & 13 \\
\hline C & 12 & 32 & $48 \cdot \overline{6}$ & $3 \cdot 5$ & 30 & 13 \\
\hline
\end{tabular}

interval was set at 25 hours, and in Cases B and C at 13 hours. The time interval was $2 \cdot 2$ times as long as the estimated $T_{2}^{1}$ in Case $A$, and 3.5 and 3.7 times as long as those in Cases $B$ and C, respectively.

The peak and blood level changes of gentamicin in these patients were followed up in the course of four repeated doses. Although the peak blood level varied in individual patients, it remained within 'therapeutic levels' and showed no tendency to accumulate (Fig. 2).

No signs of aggravating renal function, such as raised blood urea nitrogen or creatinine levels in plasma were observed and urinary examinations, including investigations of urinary sediment, showed no abnormalities throughout gentamicin treatment. No abnormalities in hearing or in vestibular function were observed in otological examinations performed before and after treatment.

\section{Discussion}

Gingell and Waterworth (1968) were the first to report that the half-life of gentamicin in serum correlated inversely with the rate of glomerular filtration as measured by renal creatinine clearance. In our study the half-life of gentamicin in our paediatric patients was shown to be significantly cor-
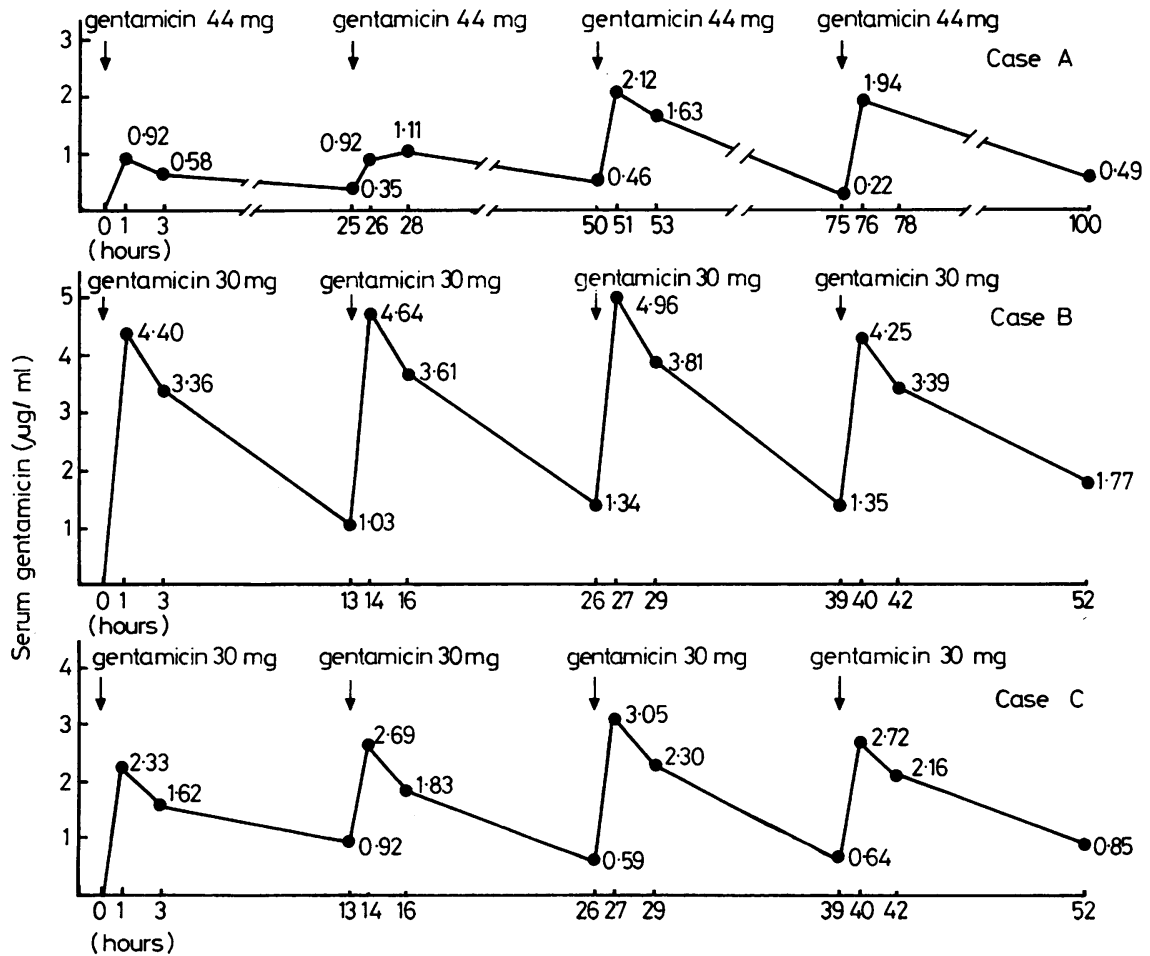

Fig. 2 Time course of serum level of gentamicin in 3 patients with renal insufficiency. Antibiotic was given repeatedly with intervals $2 \cdot 2$. $3 \cdot 5$, and $3 \cdot 7$ times as long as the calculated half-life. See Table 2 for details of patients. 
related with $\mathrm{Ccr}$, in agreement with results obtained in adult patients.

The safe upper limit for the serum level of gentamicin is believed to be $10 \mu \mathrm{g} / \mathrm{ml}$. The minimum inhibitory concentrations of gentamicin to clinically significant Gram-negative organisms range from 0.5 to $4 \mu \mathrm{g} / \mathrm{ml}$ (Garrod et al., 1973). Thus, serum levels between 5 and $10 \mu \mathrm{g} / \mathrm{ml}$ are desirable and therapeutic, but not toxic. In our study peak serum levels ranging between 3.1 and $9.4 \mu \mathrm{g} / \mathrm{ml}$, with an average of $5.5 \mu \mathrm{g} / \mathrm{ml}$, were obtained after an intramuscular dosage of $1 \mathrm{mg} / \mathrm{kg}$. These levels were clinically adequate; it rarely is necessary to administer gentamicin in excess of $1.0 \mathrm{mg} / \mathrm{kg}$ in these patients.

In order to avoid accumulation, the interval between doses of gentamicin must be prolonged in patients with renal impairment. It is desirable that the second dose be given when the serum level from the first dose falls to its lowest level. Theoretically, after an interval of twice the $T \frac{1}{2}$, the serum level is one-fourth of the peak serum level, and after three times $T_{2}^{1}$ the serum level is one-eighth. The serum level may thus be predicted to be $1.0 \mu \mathrm{g} / \mathrm{ml}$ or less at these intervals after administration. It is generally accepted that drug accumulation does not take place if the interval between doses is greater than 1.44 times $T \frac{1}{2}$ (Gibaldi and Perrier, 1975). Gingell and Waterworth (1968) confirmed that administration of gentamicin at intervals of twice the calculated $T_{\frac{1}{2}}$ is safe in a patient with a Ccr of $6.1 \mathrm{ml} / \mathrm{min}$, and they proposed an interval of three times as long as the estimated $T \frac{1}{2}$ for adult renal insufficiency.

On the basis of our own observation we feel that their proposal is justifiable, and we recommend an interval of three times the $T_{\frac{1}{2}}^{1}$ for paediatric patients as well. If the $\mathrm{Ccr}$ is known, the $\mathrm{T} \frac{1}{2}$ can probably be estimated using Fig. 1. This method of calculation appeared satisfactory in 3 patients with renal insufficiency.
Although prediction of the serum level is possible, many investigators have reported that the peak levels as well as the half-life of gentamicin in serum may vary considerably in patients with comparable renal function (Gyselynck et al., 1971; Kaye et al., 1974). In difficult cases, therefore, it is advisable to determine the actual serum levels of the antibiotic whenever possible in order to achieve the anticipated therapeutic effects and to avoid toxicity.

\section{References}

Chan, R. A., Benner, E. J., and Hoeprich, P. D. (1972). Gentamicin therapy in renal failure. A nomogram for dosage. Annals of Internal Medicine, 76, 773-778.

Cutler, R. E., Gyselynck, A.-M., Fleet, P., and Forrey, A. W. (1972). Correlation of serum creatinine concentration and gentamicin half-life. Journal of the American Medical Association, 219, 1037-1041.

Garrod, L. P., Lambert, E. P., O'Grady, F., and Waternorth, P. M. (1973). Antibiotic and Chemotherapy. Churchill Livingstone, Edinburgh and London.

Gibaldi, M., and Perrier, D. (1975). Pharmacokinetics. Dekker, New York.

Gingell, J. C., and Waterworth, P. M. (1968). Dose of gentamicin in patients with renal function and renal impairment. British Medical Journal, 2, 19-22.

Gyselynck, A.-M., Forrey, A., and Cutler, R. (1971). Pharmacokinetics of gentamicin. Distribution and plasma and renal clearance. Journal of Infectious Diseases, 124, S70-S76.

Kaye, D., Levinson, M. E., and Labovitz, E. D. (1974). The unpredictability of serum concentrations of gentamicin: pharmacokinetics of gentamicin in patients with normal and abnormal renal function. Journal of Infectious Diseases, 130, 150-154.

McHenry, M. C., Gavan, T. L., Gifford, R. W., Jr., Guerkink, N. A., van Ommen, R. A., Town, M. A., and Wagner, J. G. (1971). Gentamicin dosages for renal insufficiency. Annals of Internal Medicine, 74, 192-197.

Correspondence to Dr Hajime Yoshioka, Department of Paediatrics, Asahikawa Medical College, Kaguraoka 3-11, Kaguracho, 078-11 Asahikawa, Japan. 